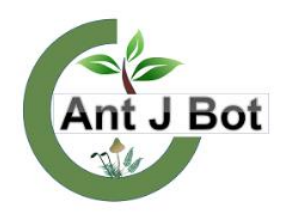

\title{
Multiple Shoot Regeneration from Shoot Tip and Nodal Explants of Rotala rotundifolia (Buch-Ham. ex Roxb) Koehne
}

\author{
Muhammet DOGAN ${ }^{1 *}$ \\ ${ }^{l}$ Karamanoglu Mehmetbey University University, Kamil Ozdag Faculty of Science Faculty, Department of \\ Biology, Karaman, Turkey \\ *mdogan01@gmail.com
}

\section{Rotala rotundifolia (Buch-Ham. ex Roxb) Koehne'nın Sürgün Ucu ve Boğum Eksplantlarından Çoklu Sürgün Rejenerasyonu}

\begin{abstract}
Rotala rotundifolia (Buch-Ham. ex Roxb) Koehne, an aquatic plant belonging to the family Lythraceae, is used for the treatment of some diseases due to its medical and anti-microbial properties. This study presents multiple shoot regeneration from shoot tip and nodal explants of $R$. rotundifolia cultured on Murashige and Skoog (MS) nutrient medium containing 0.05$1.25 \mathrm{mg} / \mathrm{L}$ Kinetin $(\mathrm{KIN})$ and $0.25 \mathrm{mg} / \mathrm{L}$ Gibberellic acid $\left(\mathrm{GA}_{3}\right)$ combinations for eight weeks. At the end of the second week, shoot formations began to be observed on the explants. High shoot regeneration frequencies were determined for both explants in the culture medium. The maximum number of shoots per explant was obtained from shoot tip (38.66) and nodal (30.77) explants cultured on MS medium containing $0.25 \mathrm{mg} / \mathrm{L} \mathrm{KIN}+0.25 \mathrm{mg} / \mathrm{L} \mathrm{GA}_{3}$. Whereas the minimum number of shoots per explant was determined on MS medium containing $1.25 \mathrm{mg} / \mathrm{L} \mathrm{KIN}+0.25 \mathrm{mg} / \mathrm{L} \mathrm{GA}$ for both explant types. The highest shoot lengths for shoot tip $(1.87 \mathrm{~cm})$ and nodal $(1.79 \mathrm{~cm})$ explants were obtained on MS culture medium containing $0.75 \mathrm{mg} / \mathrm{L} \mathrm{KIN} \mathrm{+}$ $0.25 \mathrm{mg} / \mathrm{L} \mathrm{GA} 3$ and $0.50 \mathrm{mg} / \mathrm{L} \mathrm{KIN}+0.25 \mathrm{mg} / \mathrm{L} \mathrm{GA}_{3}$, respectively. For in vitro rooting of the regenerated shoots, $2 \mathrm{~cm}$ long cut shoots were transferred to MS medium containing $0.25 \mathrm{mg} / \mathrm{L}$ indole-3-butyric acid (IBA). The rooted shoots were then successfully acclimatized to external conditions in the aquarium environment.
\end{abstract}

Keywords: In vitro, Kinetin, $R$. rotundifolia, Shoot regeneration, Tissue culture

Özet: Lythraceae familyasına ait bir su bitkisi olan Rotala rotundifolia (Buch-Ham. ex Roxb) Koehne, tıbbi ve antimikrobiyal özelliklerinden dolayı bazı hastalıkların tedavisinde kullanılır. Bu çalışma, 0,05-1,25 mg/L Kinetin (KIN) ve 0,25 mg/L Gibberellik asit $\left(\mathrm{GA}_{3}\right)$ kombinasyonları içeren Murashige ve Skoog (MS) besin ortamında sekiz hafta boyunca kültüre alınan $R$. rotundifolia'nın sürgün ucu ve boğum eksplantlarından çoklu sürgün rejenerasyonunu sunmaktadır. İkinci haftanın sonunda explantlar üzerinde sürgün oluşumları gözlemlenmeye başlanmıştır. Kültür ortamında her iki eksplant için yüksek sürgün rejenerasyon oranları belirlenmiştir. Maksimum eksplant başına sürgün sayısı, $0,25 \mathrm{mg} / \mathrm{L} \mathrm{KIN}+0,25 \mathrm{mg} / \mathrm{L} \mathrm{GA}_{3}$ içeren MS ortamında kültüre alınan sürgün ucu $(38,66)$ ve boğum $(30,77)$ eksplantlarından elde edilmiştir. Buna karşın, her iki eksplant türü için minimum eksplant başına sürgün sayıs $1,25 \mathrm{mg} / \mathrm{L} \mathrm{KIN}+0,25 \mathrm{mg} / \mathrm{L} \mathrm{GA}_{3}$ içeren $\mathrm{MS}$ ortamında belirlenmiştir. Sürgün ucu $(1,87 \mathrm{~cm})$ ve boğum $(1,79 \mathrm{~cm})$ eksplantları için en yüksek sürgün uzunlukları sırasıyla $0,75 \mathrm{mg} / \mathrm{L} \mathrm{KIN}+0,25 \mathrm{mg} / \mathrm{L} \mathrm{GA}$ ve $0,50 \mathrm{mg} / \mathrm{L} \mathrm{KIN}+0,25 \mathrm{mg} / \mathrm{L} \mathrm{GA}_{3}$ içeren MS kültür ortamında elde edilmiştir. Rejenere sürgünlerin in vitro köklendirilmesi için, $2 \mathrm{~cm}$ uzunluğunda kesilen sürgünler $0,25 \mathrm{mg} / \mathrm{L}$ indol-3-bütirik asit (IBA) içeren MS ortamına aktarılmıştır. Köklü sürgünler daha sonra akvaryum ortamında dış koşullara başarılı bir şekilde alıştırılmıştır.

Anahtar Kelimeler: In vitro, Kinetin, R. rotundifolia, Sürgün rejenerasyonu, Doku kültürü

\section{Introduction}

Aquatic plants, the primary producers of the aquatic environment, are a good source of nutrients for fish, invertebrates, and birds in tropical chains (Gross et al., 2001; Oyedeji and Abowei, 2012). They also provide habitats and refuges for periphyton, zooplankton, other invertebrate species, and vertebrates (Bornette and Puijalon, 2011). Moreover, many aquatic plants such as Bacopa monnieri (Linn.) Pennell, Alternanthera sessilis R. Brown ex DC., Hydrolea zeylanica Vahl, Ipomoea aquatica Forsskal, Limnophila indica (L.) Druce, Ludwigia adscendens (Linn.) Hara, Nymphaea nouchali N.L. Burman, Pistia stratiotes Linn. and Trapa natans Linn. have been reported for medical use in the treatment of diseases (Swapna et al., 2011).

Rotala rotundifolia (Buch-Ham. ex Roxb) Koehne (Lythraceae family) is an aquatic and amphibian plant of South and Southeast Asia, Japan, Africa, Australia, China, India and North America (Tan et al., 2009; Bhowmik et al., 2012). $R$. rotundifolia is reputed of antipyretic, detoxication, anti-swelling and diuresis properties and useful in treatments of cirrhosis ascetic fluids, gonorrhea, menstrual cramps and piles in the south of China (Zhang et al., 2011). The plant has also been used for the treatment of carbuncle, furuncle, rheumatism, and arthralgia (Tan et al., 2009). In a study to determine antioxidant and total phenolic content of 31 wetland plants, aqueous extracts of $R$. rotundifolia have been reported to have the highest antioxidant capacity (Ho et al., 2012).

The aim of this study is to investigate the efficient and rapid propagation from shoot tip and nodal explants of $R$. rotundifolia cultured on MS nutrient medium containing $0.05-1.25 \mathrm{mg} / \mathrm{L} \mathrm{KIN}$ and $0.25 \mathrm{mg} / \mathrm{L} \mathrm{GA}_{3}$ combinations. This study may help to use protocol for isolation of pharmacologically useful components from the plant and may offer an alternative method for the mass production of $R$. rotundifolia in the aquarium trade industry. 


\section{Materials and Method}

The plants of $R$. rotundifolia were obtained from the local aquarium of Konya province of Turkey. After taxonomic studies, 3-5 cm long twigs were washed under tap water for 10 minutes. Surface sterilization was performed with $20 \%$ hydrogen peroxide $\left(\mathrm{H}_{2} \mathrm{O}_{2}\right)$ for 10 min followed by rinsed thrice with sterilized distilled water by continuous stirring for $5 \mathrm{~min}$ each. After sterilization, shoot tip and nodal explants were isolated under sterile conditions and cultured on Murashige and Skoog (1962) medium (MS) devoid of growth variants (Table 1) for 2 weeks to obtain contamination free explants. Thereafter, the explants were cultured on MS medium supplemented with $3 \%$ sucrose, different concentrations $(0.05,0.25,0.50,0.75,1.00$ and $1.25 \mathrm{mg} / \mathrm{L}$ ) of Kinetin (KIN) and $0.25 \mathrm{mg} / \mathrm{L}$ Gibberellic Acid $\left(\mathrm{GA}_{3}\right)$ in Magenta $\mathrm{GA}^{7}$ vessels (Table 3 ).

Table 1. The content of Murashige and Skoog (1962) basic nutrient medium

\begin{tabular}{|c|c|c|}
\hline \multicolumn{2}{|c|}{ Components } & $\begin{array}{c}\text { Concentrations } \\
(\mathrm{mg} / \mathrm{L})\end{array}$ \\
\hline \multirow{5}{*}{ Macroelements } & $\mathrm{NH}_{4} \mathrm{NO}_{3}$ & 1650.00 \\
\hline & $\mathrm{KNO}_{3}$ & 1900.00 \\
\hline & $\mathrm{CaCI}_{2} \cdot 2 \mathrm{H}_{2} \mathrm{O}$ & 440.00 \\
\hline & $\mathrm{MgSO}_{4} \cdot 7 \mathrm{H}_{2} \mathrm{O}$ & 370.00 \\
\hline & $\mathrm{KH}_{2} \mathrm{PO}_{4}$ & 170.00 \\
\hline \multirow{9}{*}{ Microelements } & KI & 0.83 \\
\hline & $\mathrm{H}_{3} \mathrm{BO}_{3}$ & 6.20 \\
\hline & $\mathrm{MnSO}_{4} \cdot 4 \mathrm{H}_{2} \mathrm{O}$ & 22.30 \\
\hline & $\mathrm{ZnSO}_{4} \cdot 7 \mathrm{H}_{2} \mathrm{O}$ & 8.60 \\
\hline & $\mathrm{Na}_{2} \mathrm{MoO}_{4} \cdot 2 \mathrm{H}_{2} \mathrm{O}$ & 0.25 \\
\hline & $\mathrm{FeSO}_{4} \cdot 7 \mathrm{H}_{2} \mathrm{O}$ & 27.85 \\
\hline & $\mathrm{CoCl}_{2} \cdot 6 \mathrm{H}_{2} \mathrm{O}$ & 0.025 \\
\hline & $\mathrm{CuSO}_{4} \cdot 5 \mathrm{H}_{2} \mathrm{O}$ & 0.025 \\
\hline & $\mathrm{Na}_{2}$ EDTA. $2 \mathrm{H}_{2} \mathrm{O}$ & 37.25 \\
\hline \multirow{5}{*}{ Vitamins } & Myo-Inositol & 100.00 \\
\hline & Nicotinic Acid & 0.50 \\
\hline & Pyrotinic Acid & 0.50 \\
\hline & Thiamine-HCI & 0.10 \\
\hline & Glycine & 2.00 \\
\hline
\end{tabular}

The $\mathrm{pH}$ of the culture media was adjusted to $5.7 \pm 1$ before the autoclaving (1.2 atmospheric pressure, $120^{\circ} \mathrm{C}$ for 20 $\mathrm{min})$. All cultures were incubated under $16 \mathrm{~h}$ light photoperiod. After 8 weeks of culture, the experiment was terminated and the data were recorded for shoot regeneration and analyzed.

The regenerated shoots were rooted on agar-solidified MS rooting medium containing $0.25 \mathrm{mg} / \mathrm{L}$ indole-3-butyric acid (IBA) in Magenta $\mathrm{GA}^{7}$ vessels. After 4 weeks of culture, the agar medium was removed carefully from the rooted plantlets without damaging the roots by washing under running tap water. Thereafter, the plants were transferred to an aquarium containing tap water and sand for acclimatization $\left(23^{\circ} \mathrm{C}\right.$ with $16 \mathrm{~h}$ light photoperiod).

The experiment was replicated 6 times. Statistical analysis was performed as One Way ANOVA using SPSS 16 for Windows and post hoc tests were performed using Duncan. Data given in percentages were subjected to arcsine transformation (Snedecor and Cocharan, 1967) before statistical analysis

\section{Results and Discussion}

For in vitro shoot regeneration, shoot and nodal explants of $R$. rotundifolia were cultured on MS medium containing combinations of $0.05-1.25 \mathrm{mg} / \mathrm{L} \mathrm{KIN}$ and 0.25 $\mathrm{mg} / \mathrm{L} \mathrm{GA}_{3}$. At the end of two weeks, the first shoot formations were started to be observed. In the fifth week, red colorations were observed on the ends and leaves of some regenerated shoots. After eight weeks, in vitro shoot regeneration from shoot tip (Figure 1a) and nodal (Figure 1b) explants of $R$. rotundifolia was successfully achieved and then variance analysis was performed for shoot regeneration frequency, the mean number of shoots per explant, shoot length, and root regeneration frequency (Table 2). Similarly, the use of shoot tip or nodal explants for multiple shoot regeneration has been reported for some aquatic plants such as Mentha viridis L. (Raja and Arockiasamy, 2008), Veronica anagallis-aquatica L. (Shahzada et. al., 2011), Ludwigia palustris (L.) Ell. (Fontanili et al., 2015) Ceratophyllum demersum L. (Karatas et al., 2015; Emsen et al., 2016; Dogan et al., 2017) and Pogostemon erectus (Dalzell) Kuntze (Dogan et al., 2016).

As seen in Table 2, while there was no statistically significant difference in terms of root regeneration frequency, there was a statistically significant difference in shoot regeneration frequency, the mean number of shoots per explant and shoot length for shoot tip explants $(p<0.05)$. In the analysis of variance of the nodal explants, a statistically significant difference was not detected for root regeneration frequency and shoot regeneration frequency, but a statistically significant difference was found in the $99 \%$ confidence interval for mean number of shoots per explant and shoot length $(p<0.01)$. Duncan test was performed to determine the significance level of these differences (Table 3 ).

The shoot regeneration frequency was recorded between $83.33-100.00 \%$ for both explants (Table 3 ). In the shoot tip explants, $100 \%$ shoot regeneration was observed in MS medium containing $0.05-1.00 \mathrm{mg} / \mathrm{L} \mathrm{KIN}+0.25 \mathrm{mg} / \mathrm{L}$ $\mathrm{GA}_{3}$. The highest shoot regeneration frequency $(100 \%)$ in the nodal explant was obtained in the MS medium containing $0.75,1.00$ and $1.25 \mathrm{mg} / \mathrm{L} \mathrm{KIN}+0.25 \mathrm{mg} / \mathrm{L}$ $\mathrm{GA}_{3}$. Similarly, Manik et al. (2012) reported high shoot regeneration frequency (78-92\%) from shoot tip explants of Mentha piperata cultured on MS medium containing 0.75-2.0 mg/L KIN.

Mean number of shoots per explants of shoot tip and nodal explants was recorded 13.17-38.66 and 13.44-30.77, respectively (Table 3 ). The maximum number of 38.66 and 30.77 shoots per explant were obtained from shoot tip and nodal explants on MS medium supplemented with 


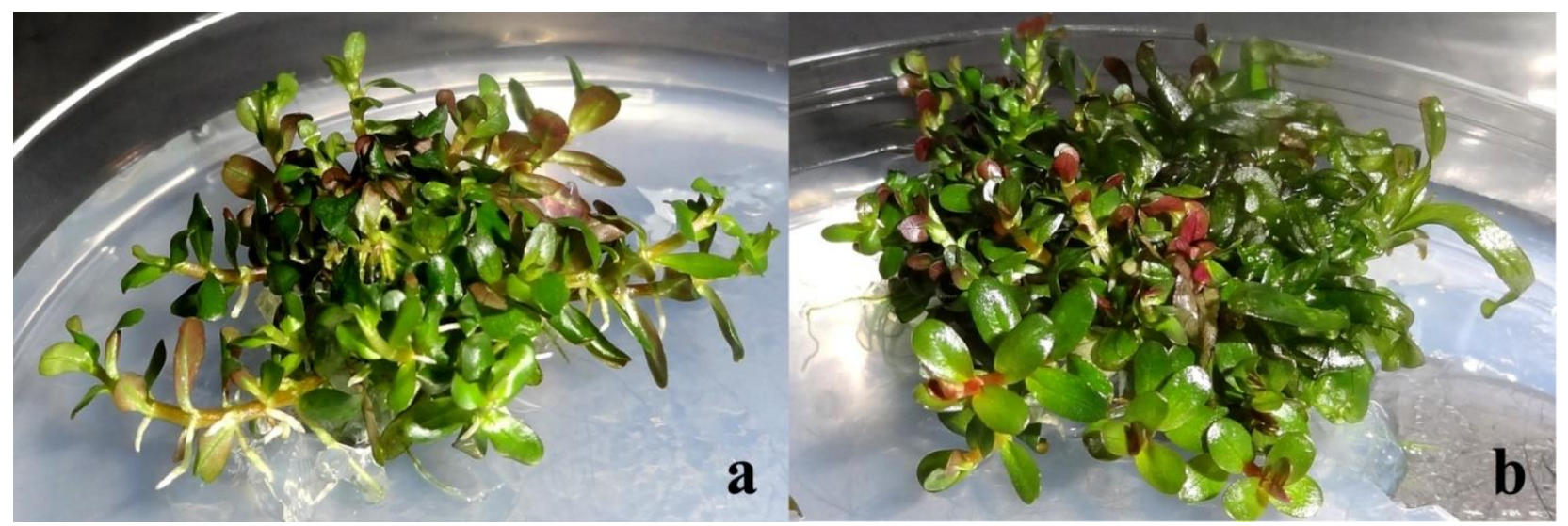

Figure 1. In vitro shoot regeneration of $R$. rotundifolia. Multiple shoot regeneration from shoot tip (a) and nodal (b) explants on MS medium containing $0.25 \mathrm{mg} / \mathrm{L} \mathrm{KIN}+0.25 \mathrm{mg} / \mathrm{L} \mathrm{GA}_{3}$ after 8 weeks of culture

Table 2. Analysis of variance of shoot tip and nodal explants of $R$. rotundifolia in MS medium containing different KIN and GA

\begin{tabular}{|c|c|c|c|c|c|c|c|c|c|}
\hline \multirow{2}{*}{$\begin{array}{l}\text { Source } \\
\text { of } \\
\text { variance }\end{array}$} & \multirow{2}{*}{$\begin{array}{c}\text { Degree } \\
\text { of } \\
\text { freedom }\end{array}$} & \multicolumn{2}{|c|}{$\begin{array}{c}\text { Shoot regeneration } \\
\text { frequency }(\%)\end{array}$} & \multicolumn{2}{|c|}{$\begin{array}{l}\text { Mean number of } \\
\text { shoots per explant }\end{array}$} & \multicolumn{2}{|c|}{ Shoot length $(\mathrm{cm})$} & \multicolumn{2}{|c|}{$\begin{array}{l}\text { Root regeneration } \\
\text { frequency }(\%)\end{array}$} \\
\hline & & $\begin{array}{c}\text { Mean } \\
\text { square }\end{array}$ & $F$ value & $\begin{array}{c}\text { Mean } \\
\text { Square }\end{array}$ & $F$ value & $\begin{array}{c}\text { Mean } \\
\text { Square } \\
\end{array}$ & $F$ value & $\begin{array}{c}\text { Mean } \\
\text { Square } \\
\end{array}$ & $F$ value \\
\hline \multicolumn{10}{|c|}{ Shoot tip } \\
\hline Medium & 5 & 138.89 & $4.00 *$ & 220.26 & $3.19 *$ & 0.26 & $4.57 *$ & 145.83 & 2.10 is \\
\hline Error & 12 & 34.72 & - & 69.13 & - & 0.06 & - & 69.44 & - \\
\hline $\begin{array}{l}\text { General } \\
\text { Total }\end{array}$ & 17 & - & - & - & - & - & - & - & - \\
\hline \multicolumn{10}{|c|}{ * Significant at $p<0.05$ level; is: Insignificant } \\
\hline \multicolumn{10}{|c|}{ Nodal } \\
\hline Medium & 5 & 138.89 & $1.333^{\text {is }}$ & 121.34 & $7.44 * *$ & 0.20 & $5.42 * *$ & 55.56 & $0.80^{\text {is }}$ \\
\hline Error & 12 & 104.17 & - & 16.30 & - & 0.04 & - & 69.44 & - \\
\hline $\begin{array}{l}\text { General } \\
\text { Total }\end{array}$ & 17 & - & - & - & - & - & - & - & - \\
\hline
\end{tabular}

Table 3. Effect of different combinations of $\mathrm{KIN}$ and $\mathrm{GA}_{3}$ on multiple shoot regeneration from shoot tip and nodal explants of $R$. rotundifolia after eight weeks of culture

\begin{tabular}{|c|c|c|c|c|c|c|c|c|c|}
\hline \multicolumn{2}{|c|}{$\begin{array}{c}\text { Plant growth } \\
\text { regulators } \\
(\mathrm{mg} / \mathrm{L})\end{array}$} & \multicolumn{2}{|c|}{$\begin{array}{l}\text { Shoot regeneration } \\
\text { frequency }(\%)\end{array}$} & \multicolumn{2}{|c|}{$\begin{array}{l}\text { Mean number of shoots } \\
\text { per explant }\end{array}$} & \multicolumn{2}{|c|}{ Shoot length $(\mathrm{cm})$} & \multicolumn{2}{|c|}{$\begin{array}{l}\text { Root regeneration } \\
\text { frequency }(\%)\end{array}$} \\
\hline KIN & $\mathbf{G A}_{3}$ & Shoot tip* & Nodal ${ }^{\text {is }}$ & Shoot tip* & Nodal $* *$ & Shoot tip* & Nodal $* *$ & Shoot tip* & Nodal $^{\text {is }}$ \\
\hline 0.05 & 0.25 & $100.00^{\mathrm{a}}$ & 83.33 & $18.83^{\mathrm{b}}$ & $16.55^{\mathrm{bc}}$ & $1.16^{\mathrm{b}}$ & $1.28^{\mathrm{abc}}$ & $100.00^{\mathrm{a}}$ & 100.00 \\
\hline 0.25 & 0.25 & $100.00^{\mathrm{a}}$ & 91.67 & $38.66^{\mathrm{a}}$ & $30.77^{\mathrm{a}}$ & $1.31^{\mathrm{b}}$ & $1.39^{\mathrm{abc}}$ & $100.00^{\mathrm{a}}$ & 100.00 \\
\hline 0.50 & 0.25 & $100.00^{\mathrm{a}}$ & 91.67 & $24.33^{\mathrm{ab}}$ & $25.92^{\mathrm{ab}}$ & $1.46^{\mathrm{ab}}$ & $1.79^{\mathrm{a}}$ & $100.00^{\mathrm{a}}$ & 100.00 \\
\hline 0.75 & 0.25 & $100.00^{\mathrm{a}}$ & 100.00 & $23.69^{\mathrm{ab}}$ & $21.25^{\mathrm{abc}}$ & $1.87^{\mathrm{a}}$ & $1.67^{\mathrm{ab}}$ & $100.00^{\mathrm{a}}$ & 100.00 \\
\hline 1.00 & 0.25 & $100.00^{\mathrm{a}}$ & 100.00 & $20.61^{\mathrm{b}}$ & $18.64^{\mathrm{bc}}$ & $1.49^{\mathrm{ab}}$ & $1.24^{\mathrm{bc}}$ & $91.67^{\mathrm{ab}}$ & 91.67 \\
\hline 1.25 & 0.25 & $83.33^{\mathrm{b}}$ & 100.00 & $13.17^{\mathrm{b}}$ & $13.44^{\mathrm{c}}$ & $1.03^{\mathrm{b}}$ & $1.13^{\mathrm{c}}$ & $83.33^{\mathrm{b}}$ & 91.67 \\
\hline
\end{tabular}

*Values followed by different small letters in the same column differ significantly at $p<0.01$

**Values followed by different small letters in the same column differ significantly at $p<0.05$

is: Insignificant 
$0.25 \mathrm{mg} / \mathrm{L} \mathrm{KIN}+0.25 \mathrm{mg} / \mathrm{L} \mathrm{GA}_{3}$, respectively. On the other hand, minimum number of shoots per explants for both explant types was determined on MS medium with $1.25 \mathrm{mg} / \mathrm{L} \mathrm{KIN}+0.25 \mathrm{mg} / \mathrm{L} \mathrm{GA}_{3}$. The results revealed that the increase in the $\mathrm{KIN}+\mathrm{GA}_{3}$ combination in the MS medium had a negative effect on the number of shoots per explant. These results are in line with Bhattacharyya and Bhattacharya (2001) who cultured the shoot tip explants of Phyllanthus amarus Schum. \&Thom. on MS medium containing 0.05-5.0 mg/L KIN and reported a decrease in the number of shoots per explant with an increase in KIN ratio. Banerjee and Shrivastava, (2008) obtained the minimum number of $8 \pm 1.86$ shoots per explant of $B$. monnieri cultured on MS medium with $2.0 \mathrm{mg} / \mathrm{L} \mathrm{KIN}$.

Shoot lengths ranged from 1.03 to $1.87 \mathrm{~cm}$ for the shoot tip explant and from 1.13 to $1.79 \mathrm{~cm}$ for the nodal explant (Table 3). The highest shoot length of shoot tip $(1.87 \mathrm{~cm})$ was obtained on MS medium containing $0.75 \mathrm{mg} / \mathrm{L} \mathrm{KIN} \mathrm{+}$ $0.25 \mathrm{mg} / \mathrm{L} \mathrm{GA}_{3}$, whereas the highest shoot length of nodal explant $(1.79 \mathrm{~cm})$ was obtained on MS medium supplemented with $0.50 \mathrm{mg} / \mathrm{L} \mathrm{KIN}+0.25 \mathrm{mg} / \mathrm{L} \mathrm{GA}$. In both explant types, the shortest shoots were determined in MS medium containing $1.25 \mathrm{mg} / \mathrm{L} \mathrm{KIN}+0.25 \mathrm{mg} / \mathrm{L} \mathrm{GA}_{3}$. Kaviani et al. (2013) reported that the longest shoots (1.20 $\mathrm{cm})$ were obtained from the shoot tip explants of
Matthiola incana on MS medium supplemented with 2 $\mathrm{mg} / \mathrm{L} \mathrm{KIN.}$

Root occurrences with KIN effect were recorded on in vitro propagation medium. For both types of explants, $100 \%$ root formation was obtained on MS medium containing $0.05-0.75 \mathrm{mg} / \mathrm{L} \mathrm{KIN}+0.25 \mathrm{mg} / \mathrm{L} \mathrm{GA}_{3}$. It has been determined that high KIN doses have an adverse effect on root formation.

In spite of root formation on the propagation medium, in vitro rooting studies of regenerated shoots were carried out in MS medium containing $0.25 \mathrm{mg} / \mathrm{L}$ IBA for four weeks. In vitro rooted plantlets were successfully acclimatized to external conditions in the aquarium environment. Similarly, successful acclimatization of in vitro regenerated aquatic plants had been reported for Cryptocoryne wendtii and Cryptocoryne beckettii (Stanly et al., 2011), A. sessilis (Gnanaraj et al., 2011), and $C$. demersum (Dogan et al., 2015).

\section{Acknowledgments}

This work was supported by the Scientific and Technological Research Council of Turkey (TUBITAK) (Project no: 2130190).

\section{References}

Banerjee M, Shrivastava S (2008). An Improved Protocol for In vitro Multiplication of Bacopa monnieri (L.). World J Microbiol Biotechnol 24: 1355-1359.

Bhattacharyya R, Bhattacharya S (2001). High Frequency In vitro Propagation of Phyllanthus amarus Schum. \&Thom. by Shoot Tip Culture. Indian J Exp Biol 39: 1184-1187.

Bhowmik S, Saha M, Datta BK (2012). Extended Distribution of Rotala rotundifolia (Buch.-Ham. ex Roxb.) Koehne (Lyhthraceae) from India. NeBIO 3: 48-50.

Bornette G, Puijalon S (2011). Response of Aquatic Plants to Abiotic Factors: a Review. Aquatic Sci 73: 1-14.

Dogan M, Emsen B, Aasim M, Yildirim E (2017). Ceratophyllum demersum L. Extract As a Botanical Insecticide for Controlling the Maize Weevil, Sitophilus zeamais Motschulsky (Coleoptera: Curculionidae). Egypt J Biol Pest Control 27: 11-15.

Dogan M, Karatas M, Aasim M (2016). In vitro Shoot Regeneration From Shoot Tip And Nodal Segment Explants of Pogostemon erectus (Dalzell) Kuntze, A Multipurpose Ornamental Aquatic Plant. Fresen Environ Bull 25: 4777-4782.

Dogan M, Karatas M, Aasim M (2015). An Efficient In vitro Plantlet Regeneration of Ceratophyllum demersum L., an Important Medicinal Aquatic Plant. Fresen Environ Bull 24: 3499-3504.

Emsen B, Dogan M, Aasim M, Yildirim E (2016). Insecticidal Activity of In vitro Propagated Aquatic Plant Ceratophyllum demersum L. against Granary Weevil Sitophilus granarius L. (Coleoptera: Curculionidae). Egypt J Biol Pest Control 26: 619-624.

Fontanili L, Lucchesini M, Mensuali-Sodi A (2015). In vitro Propagation and Shoot Encapsulation as Tools For Ex Situ Conservation of the Aquatic Plant Ludwigia palustris (L.) Ell. Plant Biosyst 149: 855-864.

Gnanaraj WE, Marimuthu J, Subramanian KM, Nallyan S (2011). Micropropagation of Alternanthera sessilis (L.) Using Shoot Tip and Nodal Segments. Iran J Biotechnol 9: 206-212.

Gross EM, Johnson RL, Hairston NG Jr (2001). Experimental Evidence for Changes in Submersed Macrophyte Species Composition Caused by the Herbivore Acentria ephemerella (Lepidoptera). Oecologia 127: 105-114.

Ho YL, Huang SS, Deng JS, Lin YH, Chang YS, Huang GJ (2012). In vitro Antioxidant Properties and Total Phenolic Contents of Wetland Medicinal Plants in Taiwan. Bot Stud 53: 55-66.

Karatas M, Dogan M, Emsen B, Aasim M (2015). Determination of In vitro Free Radical Scavenging Activities of Various Extracts From In Vitro Propagated Ceratophyllum demersum L.. Fresen Environ Bull 24: 2946-2952.

Kaviani B, Hesar AA, Tarang A, Zanjani SB, Hashemabadi D, Ansari MH (2013). Effect of Kinetin (Kn) and Naphthalene Acetic Acid (NAA) on the Micropropagation of Matthiola incana Using Shoot Tips, and Callus Induction and Root Formation on the Leaf Explants. Afr J Agric Res 8: 4134-4139.

Manik SR, Yatoo GM, Ahmad Z, Nathar VN (2012). Direct Organogenesis of Mentha piperata L. from Shoot Tip, Nodal and Sucker Explants. J Agr Tech 8: 663-669. 
Murashige T, Skoog F (1962). A Revised Medium for Rapid Growth and Bioassays with Tobacco Tissue Cultures. Physiol Plant 15: 473-497.

Oyedeji AA, Abowei JFN (2012). The Classification, Distribution, Control and Economic Importance of Aquatic Plants. Int J Fish and Aqua Sci 1:118-128.

Raja HD, Arockiasamy DI (2008). In vitro Propagation of Mentha viridis L. from Nodal and Shoot Tip Explants. Plant Tissue Cult Biotechnol 18: 1-6.

Shahzad A, Parveen S, Fatema M (2011). Development of a Regeneration System Via Nodal Segment Culture in Veronica anagallis-aquatica L. - An Amphibious Medicinal Plant. J Plant Interact 6: 61-68.

Snedecor GW, Cochran WG (1997). Statistical Methods. The Iowa State University Press, Iowa. USA.

Stanly C, Bhatt A, Keng CL (2011). An Efficient In vitro Plantlet Regeneration of Cryptocoryne wendtii and Cryptocoryne becketti through Shoot Tip Culture. Acta Physiol Plant 33: 619-624.

Swapna MM, Prakashkumar R, Anoop KP, Manju CN, Rajith NP (2011) A Review on the Medicinal and Edible Aspects of Aquatic and Wetland Plants of India. J Med Plants Res 5: 7163-7176.

Tan QG, Cai XH, Feng T, Luo XD (2009). Megastigmane-type Compounds from Rotala rotundifolia. Chin J Nat Med 7: 187189.

Zhang LJ, Yeh SF, Yu YT, Kuo LMY, Kuo Dr YH (2011). Antioxidative Flavonol Glucuronides and Anti-HBsAg Flavonol from Rotala rotundifolia. J Tradit Complement Med 1: 57-63.

Cite this article: Doğan M (2017). Multiple Shoot Regeneration from Shoot Tip and Nodal Explants of Rotala rotundifolia (Buch-Ham. ex Roxb) Koehne. Anatolian Journal of Botany 1(1): 4-8. 